\title{
Light and electronic observations on Henneguya ghaffari (Myxosporea, Bivalvulida) infecting the gills and intestine of Nile perch Lates niloticus (Pisces: Teleostei) from Chad and Senegal
}

\author{
B. Kostoïngué ${ }^{1}$, M. Fall ${ }^{2}$, C. Diébakaté ${ }^{2}$, N. Faye ${ }^{2}$, B. S. Toguebaye ${ }^{2, *}$ \\ ${ }^{1}$ Department of Biology, Faculty of Sciences, University of N'Djaména, PO Box 1027, Chad \\ ${ }^{2}$ Laboratory of Parasitology, Department of Animal Biology, Faculty of Sciences and Technologies, \\ University CA Diop of Dakar, PO Box 5005, Senegal
}

\begin{abstract}
Henneguya ghaffari Ali, 1999, described for the first time in Egypt, has been found on gills and intestine of Nile perch Lates niloticus L. from Chad and Senegal (Africa). It formed plasmodia which induced lesions of infected tissues. In fresh state, the spore body was ovoid and its size was 11.07 \pm 0.7 (range 11 to 13 ) $\times 7.7 \pm 0.4$ (range 7 to 8 ) $\mu \mathrm{m}$. The length of the caudal appendages was $44.2 \pm 1.7$ (42 to 48 ) $\mu \mathrm{m}$. The polar capsules were pyriform, of equal size, with the polar filament showing 4 coils, and measuring $3.17 \pm 0.1$ (range 3 to 4 ) $\times 2.2 \pm 0.1$ (range 1 to 2 ) $\mu \mathrm{m}$. The total length of the spore was $55.73 \pm 1.7$ (range 53 to 61 ) $\mu \mathrm{m}$. At ultrastructural level, our results confirm that in Henneguya species, the sporoplasm is binucleate and the pansporaoblast is disporous.
\end{abstract}

KEY WORDS: Myxosporea · Henneguya ghaffari · Ultrastructure $\cdot$ Fish $\cdot$ Chad $\cdot$ Senegal

Resale or republication not permitted without written consent of the publisher

The Nile perch Lates niloticus L. is a fish of great economic importance in Chad and Senegal. During the study of its parasites, Henneguya ghaffari Ali, 1999 was found infecting gills and intestine.

Myxosporea have a significant role as pathogens of marine and freshwater fishes in wild and cultured stocks (Sakiti et al. 1990, 1996, 1999, El-Matbouli et al. 1992, Lom \& Dykovà 1992, Alvarez-Pellitero \& SitjaBobadilla 1993, Branson et al. 1999, Palenzuela et al. 1999, Munoz et al. 2000). In Africa, some of these parasites have been found in freshwater fishes (Paperna 1973, 1996, Fomena et al. 1985, 1993, Fomena \& Bouix 1986, 1987, 1997a,b, Faisal \& Shalaby 1987, Obiekezie \& Okaeme 1987, 1990, Sakiti et al. 1991, 1999, Kostoïngué \& Toguebaye 1994, Kabré et al. 1995, 1997, Kostoïngué et al. 1998, 1999, 2001, Ali 1999). The present paper is a description by light and electronic microscopy of Henneguya ghaffari found in Chad and Senegal.

Materials and methods. Eighty-six specimens of Nile perch Lates niloticus were caught in Chari and Logone rivers near N'Djaména (Chad) and in the Senegal River near Djoudj Parc (Senegal) and dissected for parasite research. A myxosporean, Henneguya ghaffari, was found in the gills and intestine of some of the fish.

For light microscopy studies, fresh plasmodia were used for measuring the size of living spores, and 37 measurements were made. For histological studies, fish tissues were fixed in Carnoy's solution and embedded in paraffin. Sections (5 to $7 \mu \mathrm{m}$ ) were stained with hematoxylin-eosin.

For ultrastructural studies, fresh cysts were fixed at $4{ }^{\circ} \mathrm{C}$ with $2.5 \%$ glutaraldehyde in $0.1 \mathrm{M}$ sodium cacodylate buffer ( $\mathrm{pH}$ 7.2) for $24 \mathrm{~h}$, then post-fixed at $4{ }^{\circ} \mathrm{C}$ with $1 \%$ osmium tetroxide in the same buffer for $1 \mathrm{~h}$. After dehydration through a gradual ethanol and propylene oxide series, the cysts were embedded in Spurr resin. Ultrathin sections were made and stained with uranyl acetate and lead citrate, and examined under a Jeol 100 CXII electron microscope. Semithin sections were stained with Toluidine blue and examined under a light microscope.

For scanning electron microscopy (SEM), spores were smeared on circular cover glasses, lightly airdried and fixed in $2.5 \%$ glutaraldehyde in $0.1 \mathrm{M}$ sodium cacodylate buffer ( $\mathrm{pH} 7.2$ ) at $4^{\circ} \mathrm{C}$ for $12 \mathrm{~h}$. After washing in the buffer, and critical point drying, the smears were covered with metallic gold and paladium and observed with a Jeol 35CF SEM.

Results. Location of the parasite in the host: The plasmodia were found in the intestine and in the middle and at the base of the gill filaments (Fig. 1) in 23 of 

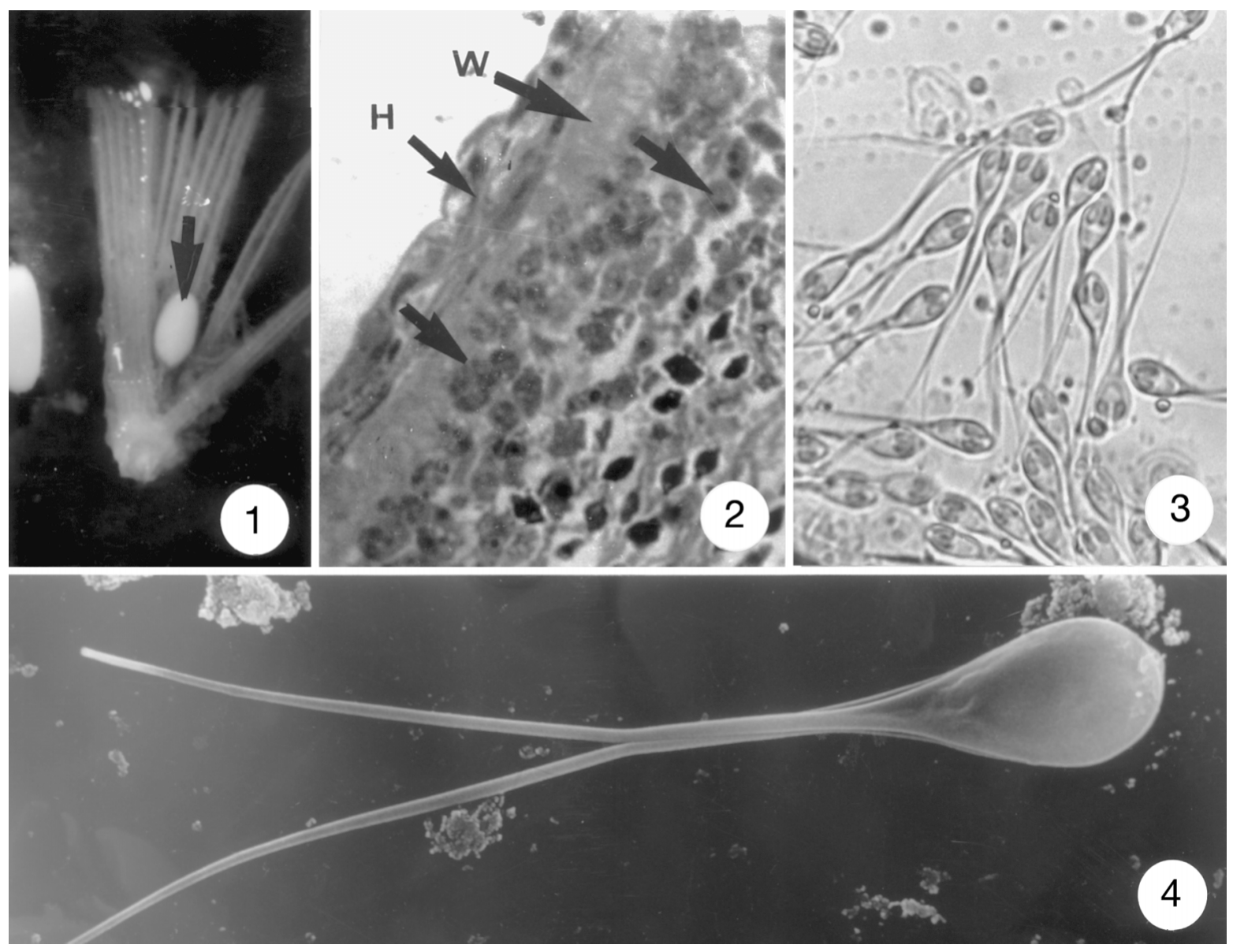

Figs. 1 to 4. Localizations and mature spores of Henneguya ghaffari. Fig. 1. Cyst (arrows) on gill filaments. Fresh preparation $(\times 60)$. Fig. 2. Semi-thin section of a cyst infecting the gill filament. The developmental stages (arrows) are located at the periphery of the cyst. Toluidine blue stain. H: host tissue; W: wall $(\times 600)$. Fig. 3. Numerous fresh spores (×600). Fig. 4. Mature spore observed in scanning electron microscope $(\times 5200)$

67 specimens from Chad $(34.3 \%)$, and 7 of 19 specimens from Senegal $(36.8 \%)$. The plasmodia were whitish, ellipsoidal and measured 0.5 to $2 \mathrm{~mm}$ long. The intensity of infection was low (the cysts were generally found in low numbers).

Sections of infected intestine show that the plasmodia were located in the epithelium. On the gill filaments, the plasmodia were intralamellar and located in the epithelium of secondary gill lamellae (Fig. 2). These plasmodia induced lesions of infected epithelial tissues.

Description of the parasite: At the light microscopic level, the sporogenesis is asynchronous with younger stages located at the periphery of plasmodia (Fig. 2). The facing view showed that the spore had an ovoid body with a rounded anterior end (Figs. 3 to 5). The tails were composed of 2 bifurcated filaments. The polar capsules, within which the polar filaments showed 4 coils, were equal in size and pyriform.

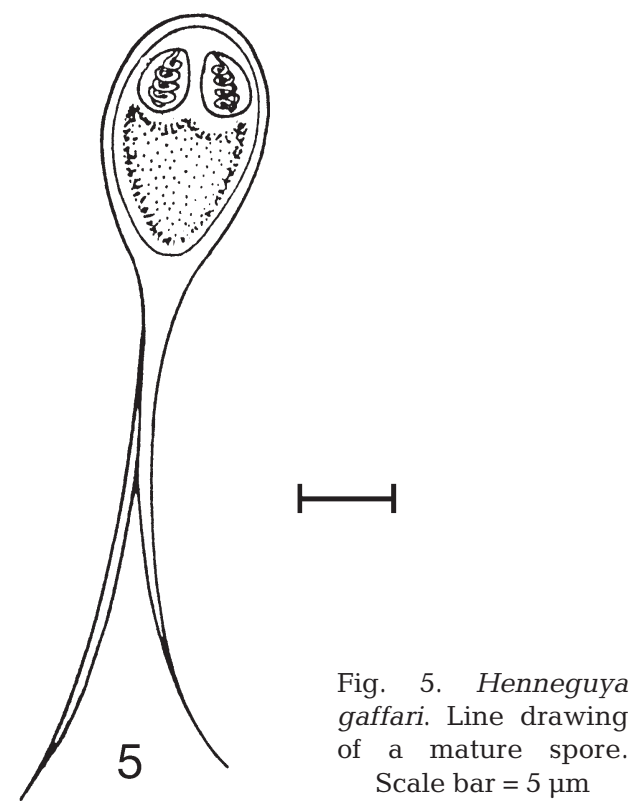



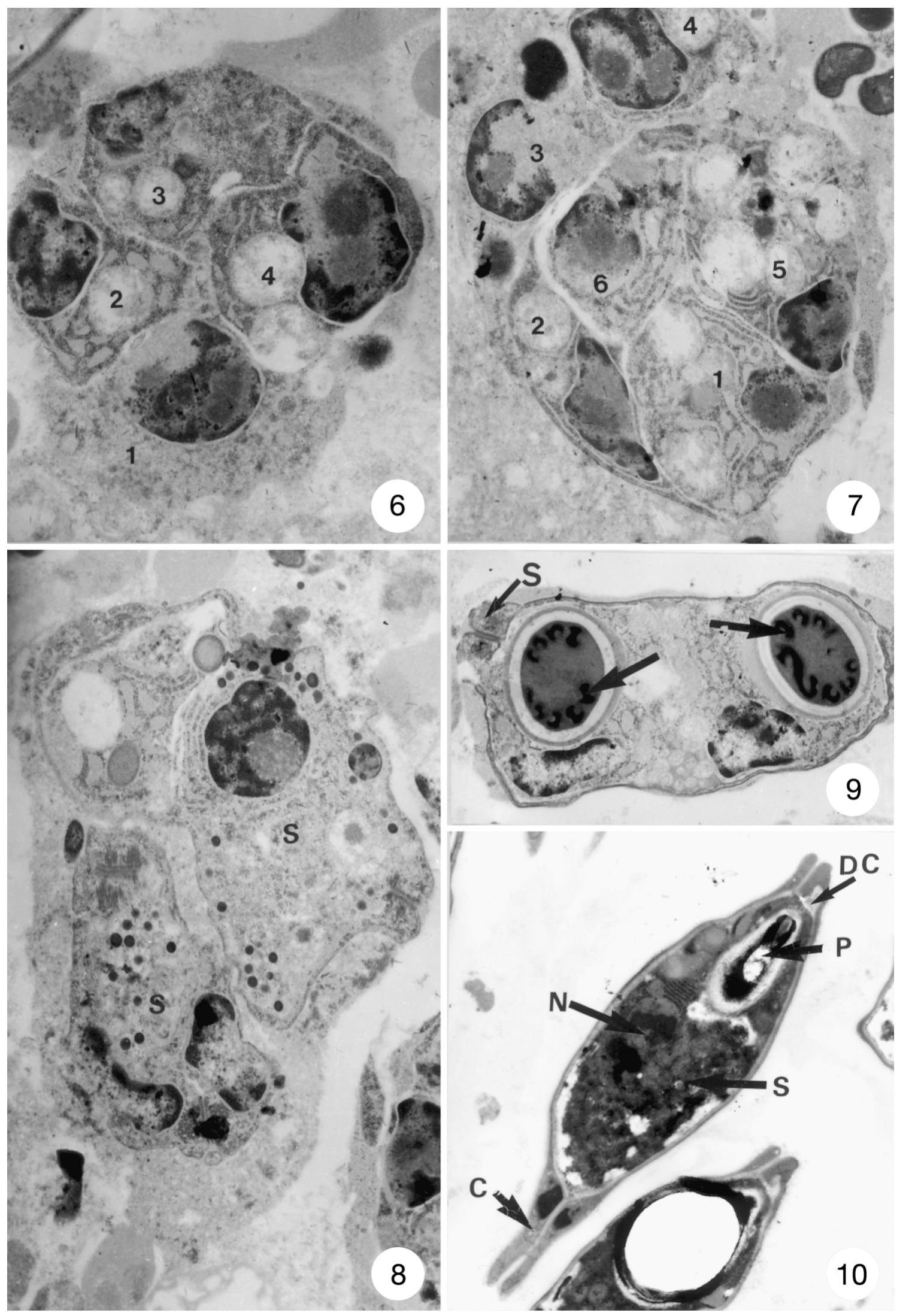

Figs. 6 to 10. Ultrastructure of Henneguya ghaffari. Fig. 6. Pansporoblast with 4 cells (labelled $\times$ 16000). Fig. 7. Pansporoblast with 6 cells (labelled $\times 16000)$. Fig. 8. Pansporoblast with 2 sporoblasts $\left(S_{;} \times 16000\right)$. Fig. 9. Developing spore containing nearly mature polar capsule with polar filament (arrows). S: sutural ridge $(\times 16000)$. Fig. $\overline{10}$. Mature spore. C: caudal appendages; DC: discharge canal; N: nucleus; P: polar capsule; S: sporoplasm $(\times 16000)$ 
The sporoplasm occupied about $75 \%$ of the spore cavity. The fresh spore dimensions were as follows: spore body, $11.07 \pm 0.7$ (range 11 to 13 ) $\times 7.7 \pm 0.4$ (range 7 to 8) $\mu \mathrm{m}$; caudal appendages, $44.2 \pm 1.7$ (range 42 to 48) $\mu \mathrm{m}$ long ; polar capsules, $3.17 \pm 0.1$ (range 3 to 4 ) $\times$ $2.2 \pm 0.1$ (range 2 to 3 ) $\mu \mathrm{m}$; total length of the spore, $55.73 \pm 1.7$ (range 53 to 61 ) $\mu \mathrm{m}$.

SEM revealed that the surface of the spores was smooth (Fig. 4).

Under the transmission electron microscope, the stages of sporogenesis observed included pansporoblast with 4 cells (Fig. 6), 6 cells (Fig. 7) and 2 sporoblasts (Fig. 8). Late sporogenesis is the formation of 2 mature spores within a pansporoblast. We noted that the valvogenic cells gave rise to 2 valves surrounding the spore, which closed with a sutural ridge (Fig. 9). In the posterior region of the spore, each valve continued as a caudal projection which presented an electrondense body at its base (Fig. 10). In the anterior region, within each sutural ridge, a polar-filament discharge canal was formed (Fig. 10). The capsulogenic cell gave rise to 2 polar capsules in which the polar filaments showed 4 coils (Fig. 9). The recognizable sporoplasm was observed in mature spore (Fig.10). It was binucleate with electron-dense cytoplasm containing a few vesicles, layers of endoplasmic reticulum and numerous ribosomes.

Discussion. This study reveals that the present species is a member of the genus Henneguya Thélohan, 1892. Compared with the 19 valid Henneguya species previously described in freshwater fishes from Africa (Fomena \& Bouix 1997a,b, Kabré et al. 1997, Ali 1999, Kostoïngué et al. 1999, 2001, Fall et al. 2000), it appeared that by the dimensions and shape of its spores and by the location of its plasmodia, the present species is $H$. ghaffari described by Ali (1999) in the same host in Egypt. Indeed, according to Ali (1999) the morphometric characteristics of $H$. ghaffari are: total length of spores, 57.5 (range 48.1 to 66.5 ) $\mu m_{i}$ spore body oval, 13.0 (range 11.8 to 11.0 ) $\times 7.5$ (range 6.9 to $7.9) \mathrm{\mu m}_{\mathrm{i}}$ polar capsules pyriform, 5.2 (range 4.8 to 5.9 ) $\times 3.2$ (range 2.8 to 3.4 ) $\mu \mathrm{m}$; tail length, 43.2 (range 36.3 to 53.0$) \mu \mathrm{m}$. Chad and Senegal are new localities for this parasite.

In Lates niloticus from Chad, we have described Henneguya massii parasitizing its gill filaments (Kostoïngué et al. 2001). H. massii is dissimilar to $H$. ghaffari because its spores are smaller (total length, 20 to $23 \mu \mathrm{m}$; polar capsules, 2 to $3 \times 1$ to $2 \mu \mathrm{m}$; spore body, 8 to $9 \times 5$ to $6 \mu \mathrm{m}$; tails, 12 to $14 \mu \mathrm{m}$ ).

Commenting on the validity of 15 Henneguya species from freshwater fishes listed by Fomena \& Bouix (1997b), Ali (1999) has reported that the 3 Henneguya species mentionned by Paperna (1973) are not valid, and that $H$. branchialis Ashmawy et al. 1989 and $H$. bopeleti Fomena \& Bouix 1987 are synomyms of $H$. suprabranchiae Landsberg, 1987. We do not agree with him about $H$. bopeleti because it is very different when compared to $H$. suprabranchiae. Indeed, according to descriptions by Fomena \& Bouix (1987) and Landsberg (1987) the differences include: total length of spores, 44.7 (range 41 to 48 ) $\mu \mathrm{m}$ for $H$. bopeleti and only 37.5 (range 30.7 to 43.3 ) $\mu \mathrm{m}$ for $H$. suprabranchiae; spore body length, 17.2 (range 15 to 19 ) $\mu \mathrm{m}$ for $H$. bopeleti and only 13.5 (range 12 to 14.3 ) $\mu \mathrm{m}$ for $H$. suprabranchiae; number of polar filament turns, 7 to 9 for $H$. bopeleti and 9 to 10 for $H$. suprabranchiae; nature of the host, Bragrid fish for $H$. bopeleti and Clariid fish for $H$. suprabranchiae. On these grounds we consider that $H$. bopeleti and $H$. suprabranchiae are distinct species. Taking into account these data, and the works of Kabré et al. (1997) and Kostoïngué et al. (2001), 19 valid Henneguya species are described from freshwater fishes in Africa.

At the ultrastructural level, our study reveals that the sporogenesis does not differ from that of previously described Henneguya (Current \& Janovy 1977, Current 1979, Azevedo \& Matos 1989, Rocha et al. 1992, Kpatcha et al. 1997).

\section{LITERATURE CITED}

Ali MA (1999) Henneguya ghaffari sp. n. (Myxozoa: Myxosporea) infecting the Nile perch Lates niloticus (Teleostei: Centropomidae). Dis Aquat Org 38:225-230

Alvarez-Pellitero P, Sitja-Bobadilla A (1993) Pathology of myxosporea in marine fish culture. Dis Aquat Org 17: $229-238$

Azevedo C, Matos E (1989) Some ultrastructural data on the spore development in a Henneguya sp. parasite of the gill of a Brazilian fish. Parasitol Res 76:131-134

Branson E, Riaza A, Alvarez-Pellitero P (1999) Myxosporean infection causing intestinal disease in farmed turbot, Scophthalmus maximus (L.), (Teleostei: Scophthalmidae). J Fish Dis 22:395-399

Current WL (1979) Henneguya adiposa Minchew (Myxosporidia) in channel catfish: ultrastructure of plasmodium wall and sporogenesis. J Protozool 26:209-217

Current WL, Janovy JJ (1977) Sporogenesis in Henneguya exilis infecting the channel catfish: an ultrastructural study. Protistologica 18:157-167

El-Matbouli M, Fisher-Scherl T, Hoffmann RW (1992) Present knowledge on the life cycle, taxonomy, pathology, and therapy of some Myxosporea spp. important for freshwater fish. Annu Rev Fish Dis 2:367-402

Faisal M, Shalaby SL (1987) Myxosoma tilapiae as a new species (Myxosoma, Myxosporea) in wild Oreochromis niloticus in lower Egypt. Egypt J Vet Sci 1:73-86

Fall M, Fomena A, Kostïngué B, Diebakaté C, Faye N, Toguebaye BS (2000) Myxosporidies (Myxozoa, Myxosporea) parasites des poissons Cichlidae du Cameroun, du Sénégal et du Tchad avec la description de deux nouvelles espèces. Ann Sci Nat 21:81-92

Fomena A, Bouix G (1986) Contribution à l'étude des myxosporidies des poissons d'eau douce du Cameroun. I. 
Espèces nouvelles du genre Myxidium Bütchli, 1882. Acta Tropica 43:319-333

Fomena A, Bouix G (1987) Contribution à l'étude des Myxosporidies des poissons d'eau douce du Cameroun. III. Espèces nouvelles du genre Henneguya Thélohan, 1892 et Thelohanelus Kudo, 1933. Rev Zool Afr 101:43-53

Fomena A, Bouix G (1997a) Espèces de Myxosporidies (Myxozoa) nouvelles ou peu connues, parasites de Téléostéens d'eau douce du Sud-Cameroun. Bull Inst Fond Afr Noire Cheikh Anta DIOP Dakar, Série A 49: 117-132

Fomena A, Bouix G (1997b) Myxosporea (Protozoa: Myxozoa) of fresh water fishes in Africa: keys to genera and species. Syst Parasitol 37:161-178

Fomena A, Bouix G, Birgi E (1985) Contribution à l'étude des Myxosporidies des poissons d'eau douce du Cameroun. II. Espèces nouvelles du genre Myxobolus Bütschli, 1882. Bull Inst Fond Afr Noire, Série A 46:167-192

Fomena A, Marques A, Bouix G (1993) Myxosporidia (Myxozoa) of Oreochromis niloticus (Linnaeus, 1757) (Teleost., Cichlidae) in fish-farming pools at Melen (Yaoundé, Cameroun, Central Africa). J Afr Zool 107:45-56

Kabré GB, Sakiti GN, Marques A, Sawadogo L (1995) Myxobolus comei n. sp. et Myxobolus burkinei n. sp.: nouvelles Myxosporidies histozoïques chez Clarias anguillaris et Labeo coubie capturés dans les pêcheries au Burkina Faso (Afrique de l'Ouest). Bull Inst Fond Afr Noire Cheikh Anta DIOP Dakar, Série A 48:49-95

Kabré GB, Sakiti GN, Marques A, Sawadogo L (1997) Presence of Myxosporeans (Myxozoa, Myxosporea) of the genus Henneguya (Thelohan, 1892), parasites of fishes caught in fisheries of Burkina Faso. Bull Eur Assoc Fish Pathol 17:43-46

Kostoïngué B, Toguebaye BS (1994) Le genre Myxoblus (Myxozoa, Myxosporea) chez les poissons d'eau douce du Tchad avec la description de trois nouvelles espèces. Bull Inst Fond Afr Noire Cheikh Anta DIOP Dakar, Série A 47:63-71

Kostoïngué B, Faye N, Toguebaye BS (1998) Nouvelles espèces de Myxosporidies des genres Myxidium Bütschli, 1882 et Myxobolus Bütschli, 1882 (Myxozoa, Myxosporea) chez des poissons d'eau douce du Tchad (Afrique Centrale). J Afr Zool 112:249-259

Kostoïngué B, Fall M, Faye N, Toguebaye BS (1999) Three new myxosporidian (Myxozoa: Myxosporea) parasites of freshwater fishes from Chad (Central Africa). Acta Protozool 38:323-326

Kostoïngué B, Diébakaté C, Faye N, Toguebaye BS (2001) Presence of Myxosporidia (Myxozoa, Myxosporea) of the genus Henneguya Thélohan, 1892 in freshwater fishes from Chad (Central Africa). Acta Protozool 40:117-123

Kpatcha TK, Faye N, Diébakaté C, Fall M, Toguebaye BS

Editorial responsibility: Wolfgang Körting,

Hannover, Germany
(1997) Nouvelles espèces d'Hennguya Thélohan, 1895 (Myxozoa, Myxosporea) parasites des poissons marins du Sénégal: étude en microscopie photonique et électronique. Ann Sci Nat 13, 18:81-91

Landsberg JH (1987) Myxosporean parasites of the catfish, Clarias lazera (Valenciennes). Syst Parasitol 9:73-81

Lom J, Dykovà I (eds) (1992) Protozoan parasites of fish: development in aquaculture and fisheries scienes, No. 26. Elsevier, Amsterdam

Munoz P, Sitja-Bobadilla A, Alvarez-Pellitero P (2000) Antigenic characterization of Sphaerospora dicentrarchi (Myxospora: Bivalvulida), a parasite from European sea bass Dicentrarchus labrax (Teleostei: Serranidae). Dis Aquat Org 40:117124

Obiekezie AI, Okaeme AN (1987) Myxobilatus accessobranchialis n. sp. (Protozoa: Myxozoa) from the accessory breathing organ of cultured Heterobranchus bidorsalis Saint-Hilaire, 1809. Arch Protistenkd 134:409-414

Obiekezie AI, Okaeme AN (1990) Myxosporea (Protozoa) infections of cultured Tilapias in Nigeria. J Afr Zool 104: $77-91$

Palenzuela O, Alvarez-Pellitero P, Sitja-Bodadilla A (1999) Glomerular disease associated with Polysporoplasma sparis (Myxozoa) infections in cultured gilthead sea bream, Sparus aurata L. (Pisces: Teleostei). Parasitology 118:245-256

Paperna I (1973) Occurrence of Cnidospora infections in freshwater fishes in Africa. Bull Inst Fond Afr Noire, Série A 35:509-521

Paperna I (1996) Parasites, infections and diseases of fishes in Africa: an update. Technical Paper No. 31. Food and Agriculture Organisation, Rome

Rocha E, Matos E, Azevedo C (1992) Henneguya amazonica n. sp. (Myxozoa, Myxobolidae) parasitizing the gills of Crenicichla lepidota Heckel, 1840 (Teleostei, Cichlidae) from Amazon River. Eur J Protozool 28:273-278

Sakiti GN, Blanc E, Marques A, Bouix G (1990) Pathology of Protozoan parasites on the gill arches of Cichlid fish in Benin (West Africa). Bull Eur Assoc Fish Pathol 10:81-83

Sakiti GN, Blanc E, Marques A, Bouix G (1991) Myxosporidies (Myxozoa, Myxosporea) du genre Myxobolus Bütschli, 1882, parasites de poissons Cichlidae du Lac Nokoué au Bénin (Afrique de l'Ouest). J Afr Zool 105: 173-186

Sakiti N, Tarer V, Jacquemin D, Marques A (1996) Présence en Méditerranée occidentale d'une Myxosporidie histozoïque pathogène dans les élevages de la Daurade. Sparus aurata L. Ann Sci Nat (Ser 13), 17:13-127

Sakiti N, Kabré G, Marques A, Dossou C (1999) Gill diseases caused by Myxozoa in fishes of Inland waters of the south of Benin. J Eukaryot Microbiol 46:15A

Submitted: January 29, 2001; Accepted: August 8, 2002 Proofs received from author(s): February 14, 2003 